\title{
Narrativa e dialogicidade nas comunidades virtuais de aprendizagem
}

\author{
Ademilde Silveira Sartori 1 \\ Universidade do Estado de Santa Catarina - UDESC \\ ademilde@matrix.com.br \\ Jucimara Roesler 2 \\ Universidade do Estado de Santa Catarina - UDESC \\ jucimara@unisul.br
}

\begin{abstract}
Resumo: Walter Benjamin entende a narrativa como troca de experiências, como relação, como prática social que pressupõe interlocução. Bakhtin entende que o diálogo inclui todas as formas de comunicação verbal, além da interação face-a-face. A palavra dirigese ao outro por ser socialmente dirigida, afirma, preocupado com o diálogo como interação verbal, como realidade fundamental da língua. Ao afirmar que a palavra não pode ser dirigida para outros, Paulo Freire refere-se ao ato autoritário do ditar, do prescrever, por isso a palavra transformadora é encontro para a mudança do mundo e só pode ser dita com os outros em diálogo. A partir do estudo destes três teóricos, identifica-se o diálogo e a narrativa no ciberespaço como base para sustentação da dialogicidade na EaD baseada em Comunidades Virtuais de Aprendizagem.
\end{abstract}

Palavras-chave: Comunidades Virtuais de Aprendizagem, Narrativa; Dialogo; Educação a Distância

Abstract: Walter Benjamin knows the narrative as experiences interchange, as relationship and as a social practice that presupposes a speaker. Bakhtin understands that dialogs include all verbal communications, besides the face to face interaction. The "word" is directed to the other because it is social driven, affirms, who is worried about dialog as a social interaction and as the fundamental reality of language. When Paulo Freire affirms that the Word can not be driven to the others, he does references to the authoritarian act of to impose, to prescript, though the transformer Word is the meeting point of the change of the world and only can be expressed when a dialog exists. From the study of these three theorists, one can identify the dialog and

${ }^{1}$ Doutora em Ciências da Comunicação - ECA/USP

2 Doutoranda em Comunicação Social - PUC/RS 
the cyberspace narrative as the basis for the sustainability of Distance Education dialogism in Virtual Learning Communities.

Key-words: Virtual Learning Communities , Narrtive, Dialogue, Distance Education

Resumen: Walter Benjamin entiende la narrativa como cambio de experiencias, como relación, como práctica social que presupone interlocución. Bakhtin entiende que el diálogo incluye todas las formas de comunicación verbal, además de la interacción cara a cara. La palabra se dirige al otro por ser socialmente dirigida, afirma Bahktin, preocupado con el diálogo como interacción verbal, como realidad fundamental de la lengua. Al afirmar que la palabra no puede ser dirigida para otros, Paulo Freire se refiere al acto autoritario del dictar, del prescribir, por eso la palabra transformadora es el encuentro para el cambio del mundo y sólo puede ser dicha con los otros en diálogo. A partir del estudio de estos tres teóricos, se identifica el diálogo y la narrativa en el ciberespacio como base para sustentación del dialogo en EaD basada en Comunidades Virtuales de Aprendizaje.

Palavras-clave: Comunidades Virtuales de aprendizagem; Educación a distancia; narración; diálogo

Résumé: Walter Benjamin conçoit la narrative comme un échange d'expériences, comme une relation, comme une pratique sociale qui présume une interlocution. Bakhtin comprend que le dialogue inclut toutes les formes de communication verbale, au-delà d'une interaction face à face. On adresse la parole à un autre car elle est socialement dirigée, affirme Bahktin, se souciant que le dialogue est une interaction verbale, une réalité fondamentale de la langue. En affirmant que la parole ne peux pas être adressé devant autrui, Paulo Freire se rapporte à l'acte autoritaire dictatorial, de prescrire, ainsi donc, la parole transformatrice est la rencontre du changement du monde et ne peux être exprimée aux autres qu'en dialogue. A partir de l'étude de ces trois théoriciens, on identifie le dialogue et la narrative dans l'espace cybernétique comme base d'appui du dialogue dans la EaD basé sur les Communautés Virtuelles d'apprentissage.

Mots clé: Communautés Virtuelles d'apprentissage, Narrative ; Dialogue ; Education à Distance. 
Em O narrador (1992), texto muito conhecido de Walter Benjamin, encontramos três tipos de narradores. O primeiro, o lavrador, é sedentário e identifica-se com a prática de contar e dizer a memória do lugar onde mora, mantendo a cultura e a tradição local. O segundo, o marinheiro mercante, é agente do contar e do dizer de outros mundos, aqueles que conheceu em suas viagens - ou ouviu falar sobre. Sua arte de narrar é que permite a imaginação recriar os lugares nos quais esteve e sobre os quais conta suas histórias.

Para Benjamin, a narrativa é uma prática social na qual alguém conta algo para alguém que escuta, estando, portanto, em relação direta, imediata. Esse tipo de narração é estreitamente vinculado à tradição e entra em declínio com o surgimento da imprensa e todo o desenvolvimento tecnológico subseqüente. O romancista rouba a cena aos narradores anteriores, mas é ator isolado, comunica-se apenas de modo mediado, diferenciando-se pelo alheamento da experiência.

A transmissão de informações torna-se o modo de comunicação em voga e a troca de experiências, tão cara a Benjamin, não pertence mais às práticas narrativas. É o fim da narração como tradição.

Na substituição do antigo relato pela informação e da informação pela sensação, reflete-se a atrofia progressiva da experiência. Todas estas formas se separam, por sua vez, da narração, que é uma das formas mais antigas de comunicação. (BENJAMIN, 1975, p. 40).

Em processo lento, mas contínuo a nossa sociedade passou a desconsiderar a troca de experiência como arte de narrar, e conforme nos relata Gagnebin (1999, p. 59):

A primeira guerra consagrou a queda da experiência e da narração; aqueles que escaparam das trincheiras voltaram mudos e sem experiências a compartilhar, nem histórias a contar. A primeira guerra manifesta, com efeito, a sujeição do indivíduo às forças impessoais e todo-poderosas da técnica, que só faz crescer e transforma cada vez mais nossas vidas de maneira tão total e tão rápida que não conseguimos assimilar essas mudanças pela palavra.

Os tradicionais narradores da concepção de Benjamin são estranhos ao nosso tempo, o que torna igualmente estranha a narração como forma de contar e dizer histórias que vão de boca-em-boca. Contudo, revelam que a narrativa entendida 
como forma de comunicação baseada na troca de experiências é fenômeno social que só ocorre entre sujeitos que se encontram em relação. A relação entre sujeitos tornase condição indispensável para a inter-locução, para o diálogo.

Pensando a comunicação por outro ângulo, Mikhail Bakhtin vê o diálogo como algo que se realiza com palavras, as quais apresentam algumas determinações como o fato de ter procedência e de ser dirigida para alguém:

Ela é determinada tanto pelo fato de que procede de alguém, como pelo fato de que se dirige para alguém. Ela constitui justamente o produto da interação do locutor e do ouvinte. Toda palavra serve de expressão de um em relação ao outro. Através da palavra, defino-me em relação ao outro, isto é, em última análise, à coletividade. (BAKHTIN, 1999, p. 113). (Grifos do autor).

A palavra é função do interlocutor e, uma vez que é proferida para comunicar algo a alguém, tem caráter social. Para o autor, a palavra é dispositivo da comunicação verbal, pois é a "realidade fundamental da língua" (BAKHTIN, op. cit., p. 123). Desse modo, o diálogo é uma categoria ampla que inclui em seu raio de ação, além da comunicação inter-pessoal, todas as formas de comunicação.

Como dispositivo de pronunciação do mundo, Paulo Freire afirma que a palavra é o próprio diálogo que, por sua vez, se caracteriza como modo de refletir e agir na realidade:

Se é dizendo a palavra com que, "pronunciando" o mundo, os homens o transformam, o diálogo se impõe como caminho pelo qual os homens ganham significação enquanto homens. Por isto, o diálogo é uma exigência existencial. E, se ele é o encontro em que se solidarizam o refletir e o agir de seus sujeitos endereçados ao mundo a ser transformado e humanizado, não pode reduzir-se a um ato de depositar idéias de um sujeito no outro, nem tampouco tornar-se simples troca de idéias a serem consumidas pelos permutantes. (...) É um ato de criação. (FREIRE, 1987, p. 79). (Grifos do autor).

Freire é autor da mais respeitada teoria comunicacional desenvolvida por pensadores latino-americanos. Para ele, a comunicação é o diálogo que pronuncia o mundo e, dentro desta perspectiva, a educação é um ato comunicativo. Com base nestes conceitos de comunicação e de educação, Freire descreve a prática educativa que se desenvolve usualmente em nossas escolas como "bancária'. 
A educação bancária é definida como aquela em que o professor não comunica, mas emite comunicados, transmite conteúdos, dissertando sobre eles. A transmissão de conteúdo fragmentário, retirado da totalidade que lhe confere significado, orienta a relação pedagógica, que , deste modo, é autoritária, burocrática e monológica.

Freire (op. cit. , p. 57) define educação bancária como:

o educador é o que educa; os educandos, os que são educados;

o educador é o que sabe; os educandos, os que não sabem;

o educador é o que pensa; os educandos, os pensados;

o educador é o que diz a palavra; os educandos, os que a escutam docilmente;

o educador é o que disciplina; os educandos, os disciplinados;

o educador é o que opta e prescreve sua opção; os educandos, os que seguem a prescrição;

o educador é o que atua; os educandos, os que têm a ilusão de que atuam, na atuação do professor;

o educador escolhe o conteúdo programático; os educandos, jamais ouvidos nesta escolha, se acomodam a ele;

o educador identifica a autoridade do saber com sua autoridade funcional, que opõe antagonicamente à liberdade dos educandos; estes devem adaptar-se às determinações daquele;

o educador, finalmente, é o sujeito do processo; os educandos, meros objetos. (FREIRE, op. cit., p. 59).

O aluno, nesta concepção educacional, é um receptor passivo de informações e o professor tem o papel de fonte principal e conduz todo o processo. "Nela, o educador aparece como seu indiscutível agente, como o seu real sujeito, cuja tarefa indeclinável é 'encher' os educandos dos conteúdos de sua narração" (FREIRE, op. cit., p. 56). O modelo bancário centra-se na transmissão de informações, por isso ordena e atribui uma seqüência aos conteúdos, que são administrados de modo controlado, a partir do planejamento realizado previamente e seguido à risca, e cujo não cumprimento é entendido como problema a ser solucionado urgentemente. 
Em sentido oposto, concebe a educação dialógica, também denominada problematizadora, libertadora, ou ainda transformadora -, que atribui papel ativo ao aluno e a relação educador-educandos é mediatizada pelo objeto do conhecimento. O diálogo é estabelecido sem hierarquia, com o permanente intercâmbio entre os papéis de educador e o de educando. A apreensão significativa da realidade passa a ser o critério de estruturação do conteúdo a ser discutido e o conhecimento é construído pelo coletivo educador-educandos.

O diálogo é entendido nesta concepção como "problematização do próprio conhecimento e sua indiscutível relação com a realidade concreta na qual se gera e sobre a qual incide, para melhor compreendê-la, explicá-la, transformá-la” (FREIRE, op. cit., p. 52). O conhecimento não é transmissão de algo pronto e acabado, mas é uma construção a partir da intervenção na realidade.

O conhecimento, pelo contrário, exige um a presença curiosa do sujeito em face do mundo. Requer sua ação transformadora sobre a realidade. Demanda uma busca constante. Implica em invenção e em reinvenção. Reclama a reflexão crítica de cada um sobre o ato mesmo de conhecer, pelo qual se reconhece conhecendo e, ao reconhecer-se assim, percebe o "como" de seu conhecer e os condicionamentos a que está submetido seu ato. (FREIRE, 1979, p. 27).

A dialogicidade é uma categoria cara à compreensão freireana de comunicação, uma vez que compreende o diálogo como interlocução entre sujeitos aprendentes e atuantes, trazendo em seu conteúdo a noção de conhecimento como sinônimo de ação política. Conhecer, para este autor, é atuar no mundo e esta ação não ocorre sem comprometimento.

Em seu livro Comunicação ou Extensão (1979), Freire discute como uma ação extensionista não pode ser compreendida como ação educativa, a não ser em uma perspectiva transmissivista do conhecimento, de uma ação sobre as pessoas, uma invasão cultural. Ao contrário, comunicar-se significa uma ação conjunta, libertadora, em que educandos e educadores interagem de modo a pronunciar o mundo, significando-o.

A partir das categorias de narrativa, em Benjamin, e de diálogo em Bakhtin e Freire, identifica-se estas duas categorias como base para a dialogicidade na EaD baseada em Comunidades Virtuais de Aprendizagem. 
A modalidade educativa a distância necessita das tecnologias de comunicação para efetuar sua proposta pedagógica e, ao utilizar a rede, cria Comunidades Virtuais de Aprendizagem. Para Rheingold (1996, p.18) "comunidades virtuais são os agregados sociais surgidos na Rede, quando os intervenientes de um debate o levam por diante em número e sentimento suficientes para formarem teias de relações pessoais no ciberespaço". As CVAs são comunidades virtuais dedicadas a processos educativos. O sentido da existência de uma CVA é a ação coletiva dentro de uma situação gnosiológica.

Neste sentido, as Comunidades Virtuais de Aprendizagem representam a possibilidade de uma troca de saberes, já que a interlocução no grupo cria a possibilidade de uma identidade compartilhada, bem como novas possibilidades de construção do conhecimento. Em uma CVA, as relações realizam-se mediadas pelo computador, o qual passa a ser um território da ação a distância das pessoas, pois ali se materializam as relações sociais, culturais e de conhecimento.

Ao garantir os fluxos informacionais, o compartilhamento de mensagens, a realização de atividades e discussões, os dispositivos de comunicação proporcionam a troca de experiência, viabilizando a interlocução entre os sujeitos na medida em que possibilitam ouvir o outro, assim, tornam a CVA um espaço para viabilizar a narrativa como troca de experiências.

Nesse contexto, a CVA como possibilidade de tornar presente a experiência vivificada pelas ações a distância daqueles que fazem parte de um projeto de aprendizagem é propiciadora de diálogo.

Compartilhar a informação, os interesses e os recursos é parte integrante da educação on-line. É a base da forma construtiva de ensinar e aprender, em que o conhecimento e o significado é criado em conjunto pelos alunos e professor (PALLOFF ; PRATT, 2004, p. $38)$.

Superar a educação bancária para uma prática educacional problematizadora é proporcionar a construção coletiva do conhecimento através das narrativas que encontramos nos materiais didáticos e nas interlocuções que ocorrem durante o processo de interação com os textos disponíveis, com os professores e colegas. Ou seja, o processo inicia na elaboração do desenho pedagógico e se concretiza na ação educacional, pois: 
O desenho pedagógico de um curso a distância é composto pela definição do público-alvo, dos objetivos educacionais, da organização curricular, da arquitetura de distribuição dos conteúdos, das mídias que irão proporcionar a interação e do sistema de avaliação da aprendizagem. (SARTORI; ROESLER, 2005, p. 142).

Ao escrever o material didático o autor estabelece um canal de interlocução com os estudantes. Os responsáveis pela gestão da aprendizagem potencializam essa interlocução por meio de uma arquitetura de distribuição dos conteúdos e dos dispositivos de gestão pedagógica e de comunicação. Em uma educação problematizadora, estes dispositivos precisam ser pensados para garantir a interpretação, imaginação e a intervenção nas narrativas, naquelas construídas no material didático pelo autor, e, nas que são construídas pelo coletivo durante a interação.

Em projetos de educação a distância baseados em CVA, a narrativa enquanto diálogo manifesta-se tanto na elaboração do material didático quanto nas relações entre os envolvidos, pois, o elaborador considera os alunos como seus interlocutores, dirigindo-lhes a palavra e, na medida em que representa uma visão de mundo, a palavra pronunciada pelos sujeitos durante o processo de interação, construída a partir da intervenção na realidade, é transformadora e encontro para a mudança do mundo. 


\section{Referências:}

BAKHTIN, M. Marxismo e filosofia da linguagem. Trad. Michel Lahud e Yara F. Vieira, 9ª ed. São Paulo: 1999.

BENJAMIN, W. O narrador. Reflexões sobre a obra de Nikolai Lesskov. In Sobre Arte, Técnica, Linguagem e Política. Trad. Maria Amélia Cruz. Lisboa: Relógio D’Água, 1992.

. A modernidade e os modernos. Trad. De Krieger Mendes da Silva, Arlete de Brito e Tânia Jatobá. Rio de Janeiro: 1975. Coleção Biblioteca Tempo Universitário.

BRAIT, B. (org.). : conceitos-chave. São Paulo: Contexto, 2005.

FREIRE, P. Pedagogia do oprimido. 17 ed. Rio de Janeiro: Paz e Terra, 1987.

. Comunicação ou extensão? Trad. De Rosisca Darcy de Oliveira. $4^{\mathrm{a}}$ ed., Rio de Janeiro: Paz e Terra, 1979.

. Pedagogia da esperança. Um reencontro com a Pedagogia do oprimido. 11 a ed, Rio de Janeiro: Paz e Terra, 2003.

GAGNEBIN, J. M. História e narração em Walter Benjamin. São Paulo: Editora Perspectiva, 1999.

RHEINGOLD, H. A Comunidade Virtual. Editora Gradiva, Lisboa, 1996.

SARTORI, A. ROESLER, J. Educação Superior a Distância. Gestão da aprendizagem e da produção de materiais didáticos impressos e online. Tubarão: Editora Unisul, 2005. 